OPEN ACCESS

Edited by:

Anoop Ambili,

Indian Institute of Science Education and Research Mohali, India

Reviewed by: Zoltan Kern,

Hungarian Academy of Sciences (MTA), Hungary

José Darrozes,

UMR5563 Géosciences

Environnement Toulouse (GET),

France

*Correspondence:

Krishna G. Misra

kgmisrabsip@gmail.com

Specialty section:

This article was submitted to Quaternary Science, Geomorphology and Paleoenvironment, a section of the journal Frontiers in Earth Science

Received: 24 December 2020 Accepted: 18 May 2021

Published: 31 May 2021

Citation:

Misra KG, Singh V, Yadava AK,

Misra S, Maurya RS and Vishwakarma S (2021) Himalayan Blue Pine Deduced Precipitation Record from Cold Arid Lahaul-Spiti, Himachal

Pradesh, India.

Front. Earth Sci. 9:645959. doi: 10.3389/feart.2021.645959

\section{Himalayan Blue Pine Deduced Precipitation Record from Cold Arid Lahaul-Spiti, Himachal Pradesh, India}

\author{
Krishna G. Misra*, Vikram Singh, Akhilesh K. Yadava, Sandhya Misra, Ravi S. Maurya and \\ Sadhana Vishwakarma
}

Birbal Sahni Institute of Palaeosciences, Lucknow, India

Ecologically Himalayan blue pine (Pinus wallichiana A. B. Jackson) is the most sensitive tree-species found across the high mountain ranges of Himalaya with deciphering tree-line for the region. Earlier studies showed the potential of Himalayan blue pine to reconstruct the past climate for extending observational data back to the centuries from orographydominated Himalaya. However, tree-growth of the blue pine is largely found modulated by temperature in the western Himalayan region. In the present study, we attempted the first time to develop precipitation records using Himalayan blue pine chronology from cold arid Lahaul-Spiti, Himachal Pradesh, India. The blue pine chronology extends back to AD 1578 and showed significant relationship with the climatic variables. The bootstrap correlation analyses revealed previous year December to current year July precipitation plays significant role in tree-growth advancements. The previous year December to current year July (pDcJuly) precipitation has been reconstructed back to the AD 1730 for the Lahaul-Spiti region. The recorded individual and multi-year periods of low and high precipitation are consistent with existing hydro-climatic records from the western Himalaya. The five driest and wettest individual years are 1732, 1737, 1970, 2008, 1785 , and 1730, 1771, 1758, 1734, 1736, respectively. The spatial correlation between gridded precipitation and reconstructed pDcJuly precipitation is significant for the region close to the sampling site. The study based on the Himalayan blue pine tree-ring chronology addressed its dendroclimatic utility for the semi-arid Lahaul-Spiti region and would be valuable to understand climatic variability over the past three centuries. The strong resemblance of the species with the Himalayan cedar growth patterns showed its promising viability to develop a network of multispecies for more robust climatic reconstruction in the future.

Keywords: Himalayan blue pine, tree-ring, precipitation, climatic variability, Lahaul-Spiti, Himachal Pradesh

\section{INTRODUCTION}

The Himalayan mountain system is unique in the world due to its complex geographical distribution and young dynamic geology. The high elevated orogeny of the Himalaya in combination with the Tibetan plateau controls the climate over the region. The high-altitude Himalayan ecosystem and environment have significant effect on global climate change and the Himalayan ranges, outside the poles, contained the largest body of ice/snow in the form of glaciers and snow-caps. These glaciers and snow-caps are very sensitive to climate change and as per the IPCC report (IPCC, 2013) glaciers 
are retreating worldwide due to on-going atmospheric global warming. Global warming leads to the Earth's average temperature up to a critical level, where the average temperature showing an increase of $0.85^{\circ} \mathrm{C}$ for $1880-2012$ and since 1850 each of the last three decades has been successively warmer (IPCC, 2013). The consequences of climate changeinduced global warming are not only restricted to the rising global average temperature of the earth but also disturbing the precipitation pattern over the Himalayan region. Climate change and global warming results include the uncertainty in the pattern and intensity of precipitation which affects hydrogeological conditions over the region. Precipitation over India is mainly brought by the Indian summer monsoon (ISM), from the southern end and by western disturbances (WD) from the northern end of the sub-continent. ISM intensified in the Indian sub-continent during the period from June-September (JJAS), whereas WD reaches its optimum during December-March (DJFM). These two are the primary sources of precipitation over the whole Indian sub-continent in which $1 / 6$ th of the world population lives and depends on their livelihood. ISM directly helps the major part of peninsular India and Himalayan foothills by dropping down the temperature, recharging groundwater level by natural irrigation of the agricultural land. Whereas WD provides a major source for the feeding of glaciers and rivers of western and northwestern Himalaya and plays a significant role to maintain the hydroclimatic conditions (Yadav and Bhutyani, 2013). Based on the observation of meteorological data generated by India Meteorological Department (IMD) and gridded data in the recent past from 1901 to 2012 the summer monsoon rainfall has weakened over south Asia in general and this is very striking over the central-east and northern region of India (Roxy et al., 2015). Although a recent study from Kishtwar, Jammu \& Kashmir indicates about pluvial phase prevailing in the recent few decades over the northwest Himalaya and Karakoram (Yadav et al., 2017). The reconstruction revealed the last 31-years (1984-2014) from the past 576 years being the wettest; indicate recent strengthening of the westerly's over northwest Himalaya and Karakoram. In an agrarian economy like India, where the $2 / 3$ rd population is associated directly or indirectly with the agriculture and related sectors, uncertainty in precipitation pattern becomes the cause of huge misery for the socio-economic lives.

To understand the precipitation variability over a region it is important to access meteorological data records, but unfortunately in the Himalayan region, meteorological records are sparse and patchy. These observational records are inadequate to explain the long-term climatic variability of the region in terms of precipitation, temperature, snowfall etc. Therefore, to fill the data void and extends the existing records back to the centuries, high-resolution proxies such as tree-ring, lake sediments, ice cores, and speleothems have been studied over the decades from the Himalaya (Overpeck et al., 2005; Joshi et al., 2017; Phartiyal et al., 2020; Dahe et al., 2021; Kumar et al., 2021). However, to develop high-resolution annually resolved climatic records from centuries to millennium tree-rings proved its utility among all other proxies in the past few decades (Yadav and Park,
2000; Cook et al., 2003; Yadav et al., 2004; Tredyte et al., 2006; Singh et al., 2006, 2009; Cook et al., 2010; Yadav, 2011a, b, 2012, 2013; Yadav and Bhutiyani, 2013; Yadava et al., 2016; Singh et al., 2017; Yadav et al., 2017). In view of the great importance of treering records to provide the annually resolved climatic data, we have selected Lahaul-Spiti region in the present study for analyzing the past climate.

The Lahaul-Spiti is a semi-arid to arid cold desert situated in the northern part of Himachal Pradesh. A major portion of annual precipitation occurs in this region due to the moistureladen westerlies from December to april. Due to topographic barriers of the Pir Panjal range, summer monsoon rainfall does not reach properly over Lahaul-Spiti and it only drizzles during the peak monsoon (Yadav, 2011b). Over the western Himalaya, Lahaul-Spiti accumulates the foremost portion of ice and snow (Bajpai, 2002) and in the presence of weak ISM in the higher Himalaya; westerlies provides vital feeding to the glaciers and Himalayan rivers. To understand the climatic variability, precipitation reconstruction (Yadav, 2011b) and snowfall records (Yadav and Bhutiyani, 2013), was developed using Cedrus deodara chronologies from the cold arid Lahaul Himalaya. The Lahaul-Spiti region in the Northwest Himalaya has unique environmental setting for tree-ring studies where over millennium-long old trees growing in natural conditions are very common (Yadav, 2012; Misra et al., 2020). The potential of treering-based climate studies using Cedrus deodara and Juniperus polycarpos has been widely explored from the cold arid Lahaul-Spiti region (Yadav et al., 2006; Yadav, 2011b, 2012; Yadav and Bhutiyani, 2013). However, the dendroclimatic potential of Pinus wallichiana has not been taken into account for climatic reconstruction largely due to its patchy distribution in difficult terrains but the rate of tree-line migration was observed earlier from the region (Dubey et al., 2003; Yadava et al., 2017). Although, studies on Himalayan blue pine from different regions of the western Himalaya showed its utility in developing centuries-long chronologies, establishing tree-growth climate relationship and climatic reconstructions (Yadav et al., 1997; Singh and Yadav, 2000; Yadava et al., 2017; Shah et al., 2019). However, the climatic signals thus far reported in Himalayan blue pine chronologies in terms of moisture signal was weak and vary with the nature of the ecological settings of the tree-ring sampling sites. Here, in the present attempt, we for the first time used Himalayan blue pine from the Lahaul-Spiti region for the precipitation reconstruction.

\section{MATERIAL AND METHODS}

\section{Tree-Ring Data}

The Himalayan blue pine ( $P$. wallichiana A. B. Jackson) is a tall evergreen tree that has needle-like leaves in the form of bundles with a bluish-green tinge and therefore also known as blue pine. Himalayan blue pine is native of Himalaya and distributed all along the Himalayan Mountains generally over an altitude of $1,800-3,900 \mathrm{~m}$, starting from the east of Afghanistan to northeast India to Nepal and Bhutan (Sahni, 1990). For the present study, we collected tree-ring samples of Himalayan blue 


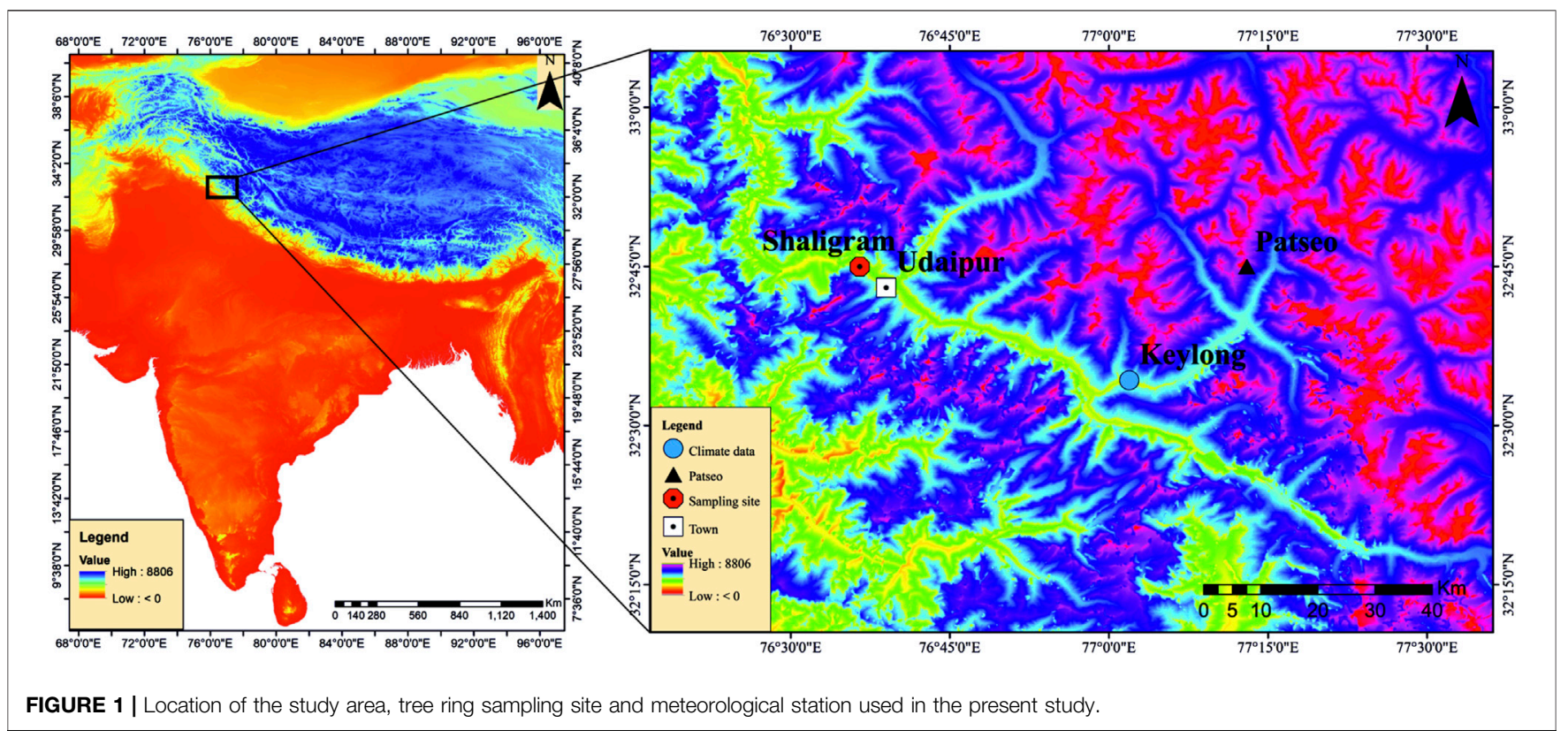

pine from Shaligram, Lahaul-Spiti, Himachal Pradesh (Figure 1) over an altitude of 3,076 m asl. At this site, Himalayan blue pine trees are growing scattered and intermixed with Himalayan cedar trees. A detailed survey was done to collect the increment cores from healthy, old Himalayan blue Pine trees. Finally, 21 samples from 15 isolated and healthy trees were selected from the cold-arid moisture stressed site in the Lahaul Himalaya. Undisturbed samples were collected from the breast height $(\sim 1.4 \mathrm{~m})$ of the stem in the direction perpendicular to the natural slope. Tree-ring increment cores were processed following the standard dendrochronological procedure (Stokes and Smiley, 1968), which includes mounting, surfacing, and polishing with different grades of abrasive. Growth ring sequences were dated using the skeleton plot method (Stokes and Smiley, 1968) and calendar age was assigned to each ring. To cross-date the tree-ring samples through the skeleton plotting method, signaling rings from each samples were plotted to the graph-strip to match the growthring patterns. Ring-widths in cross-dated samples were measured using linear encoder (LINTAB) attached to the personal computer (Rinn, 2003). The dating quality control program COFECHA was used to evaluate the accuracy of cross-dated samples which crosschecks the correlation between single measurement series and mean of all the series used in that particular segment (Holmes, 1983). Segments in the samples with problems or weak correlations were rechecked and errors corrected, if any, by comparing with master series. Samples were discarded if the correlation and cross-dating problems continue after re-examining the samples. COFECHA analyses revealed mean series intercorrelation between all individual samples is 0.64 and such good coherence among samples indicates strong year-to-year pattern matching. High correlation among all the individual series indicates the presence of common climatic signal in the tree-ring data. Except climate forcing, tree-ring sequence is also influenced by external and internal factors such as biological growth trend, disease and competition for nutrients among neighboring trees. These noises were removed and the climatic signal among all the series was maximized by curve fitting, called Standardization (Fritts, 1976) using ARSTAN program (Cook, 1985). The ring-width sequence of the Himalayan blue pine was observed cautiously for the selection of the appropriate detrending method. To detrend the ring-width measurements series $67 \%$ cubic smoothing spline with a $50 \%$ frequency response cut-off was used. Tree-ring-width series were power transformed before detrending to stabilize the variance in the individual series (Cook and Peters, 1997). After detrending, biweight robust mean (Cook, 1985) was calculated, and mean chronology (AD 1578-2016) was prepared by combining all the individual detrended series. 439 years long ring-width chronology of Himalayan blue pine was developed from the cold arid Lahaul-Spiti region (Figure 2). The chronology span for analysis depends on the threshold limit of expressed population signal (EPS) > 0.85 (Wigley et al., 1984). Replication of 21 samples from 15 trees was found to be sufficient for getting the desired EPS level. However, to stabilize the variance due to changing replication and inter-series correlation, variance adjustment (Osborn et al., 1997) was also tested but the effect was found to be insignificant so has not been applied on the calculation of the final mean ring-width index. The residual version of chronology (AD 1730-2016) based on EPS level $>0.85$ was taken into consideration for the further dendroclimatic analysis and climate reconstruction. Chronology statistics including chronology span, the number of samples used in the development of chronology, standard deviation, mean sensitivity and EPS threshold value are given in Table 1.

\section{Climate Data}

Instrumental climate records close to the sampling site are prerequisite for the tree-ring based climate reconstruction. Climate data from meteorological stations situated close to the 


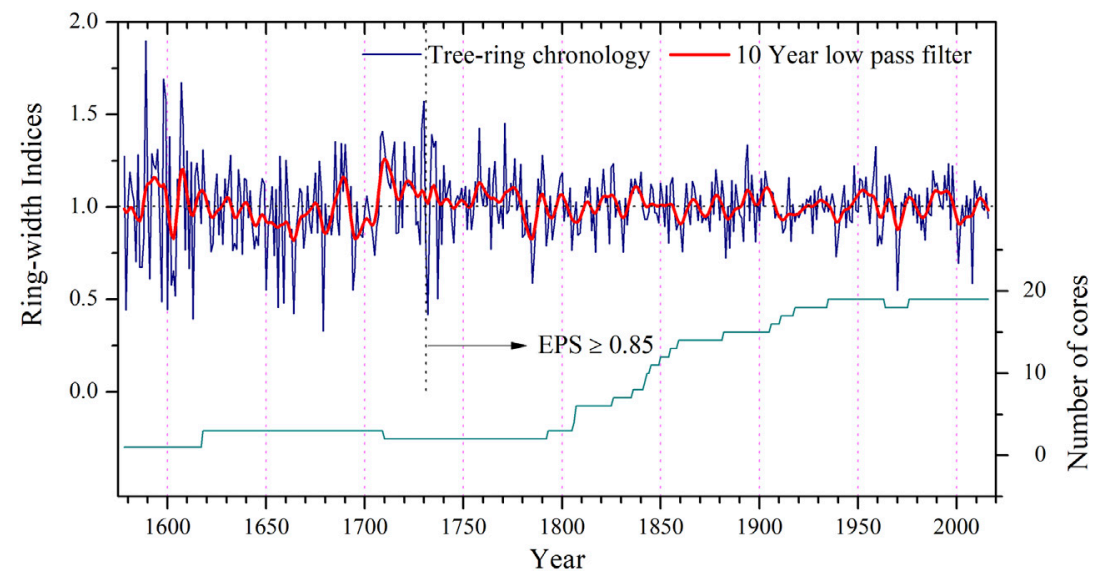

FIGURE 2 | Himalayan blue pine (Pinus wallichiana) chronology developed from Shaligram, Lahaul-Spiti, Himachal Pradesh, India (AD 1578-2016). EPS limit (0.85) of the chronology indicated by the vertical dotted line at AD 1730, after which chronology exceeds the threshold limit.

TABLE 1 | Himalayan blue pine chronology statistics developed from Shaligram, Lahaul-Spiti, Himachal Pradesh, India (AD 1578-2016).

\begin{tabular}{|c|c|c|c|c|c|c|c|c|c|}
\hline $\begin{array}{l}\text { Latitude } \\
\text { (N) }\end{array}$ & $\begin{array}{l}\text { Longitude } \\
\text { (E) }\end{array}$ & $\begin{array}{c}\text { Elevation } \\
\text { (m asl) }\end{array}$ & $\begin{array}{l}\text { Cores/ } \\
\text { trees }\end{array}$ & $\begin{array}{l}\text { Chronology } \\
\text { span } \\
\text { AD (yrs) }\end{array}$ & $\begin{array}{c}\text { Chronology } \\
\text { with } \\
\text { EPS >0.85, AD }\end{array}$ & MI & MS & SD & AR1 \\
\hline $32^{\circ} 44^{\prime} 58^{\prime \prime}-32^{\circ} 45^{\prime} 36^{\prime \prime}$ & $76^{\circ} 36^{\prime} 30^{\prime \prime}-76^{\circ} 36^{\prime} 3^{\prime \prime}$ & 3,076 & $21 / 15$ & 1,578-2016 (439) & 1730-2016 & 1.00 & 0.20 & 0.19 & 0.00 \\
\hline
\end{tabular}

EPS, expressed population signal; MI, mean index; MS, mean sensitivity; SD, standard deviation; AR1, first-order autocorrelation.

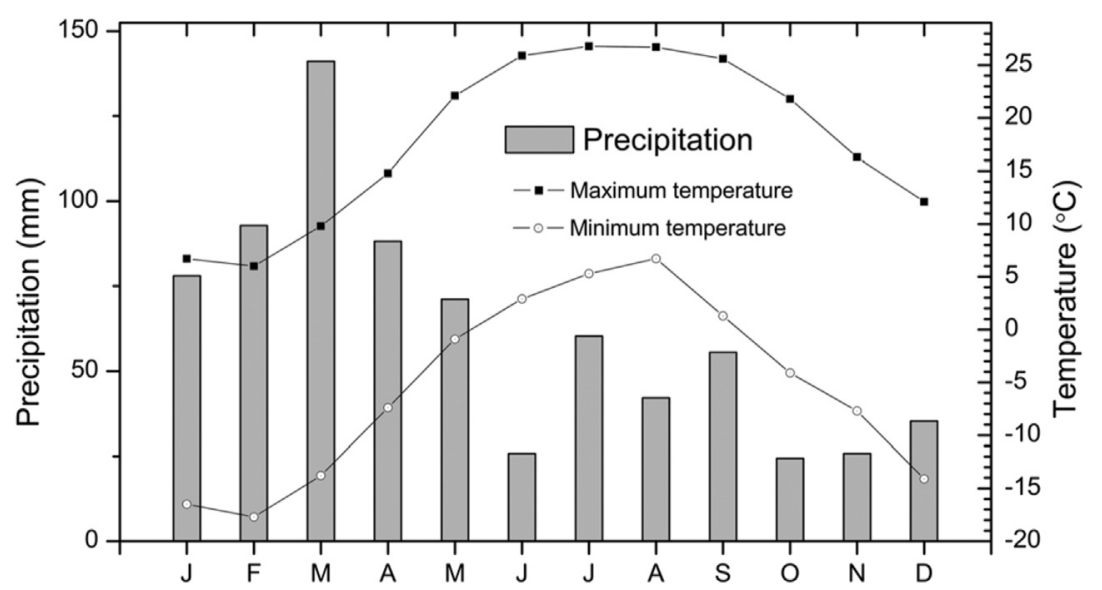

FIGURE 3 | The mean monthly precipitation pattern of Keylong and temperature of Srinagar meteorological stations used in the study.

tree-ring sampling sites explain the regional climatology better and are useful in calibration. The climate in orography dominated Himalayan region, changes within a very short distance due to altitudinal differences and mountain settings. Highly dissected orography restricts our understanding of climate variability over Himalaya on a regional scale and long-term spatial changes cannot be captured through sparsely located meteorological station data. Long and homogenous records of climate variables from the Himalaya are very few and mainly centered in the valley floors far away from the potential remote areas. Only very few stations in north India have data that extend more than a century and therefore difficulties always arise during the dendroclimatological studies (Yadav et al., 2004; Singh and Yadav, 2005). Keylong $\left(33^{\circ} 34^{\prime} \mathrm{N}, 77^{\circ} 01^{\prime} \mathrm{E}, 3,054 \mathrm{~m}\right.$ asl; $\mathrm{AD}$ $1933-1970)$ is the only station with precipitation data available close to the sampling site; with approximately $38 \mathrm{~km}$ nautical distance. The meteorological data of precipitation suggest that this cold desertic area receives maximum (about 80\%) part of its 


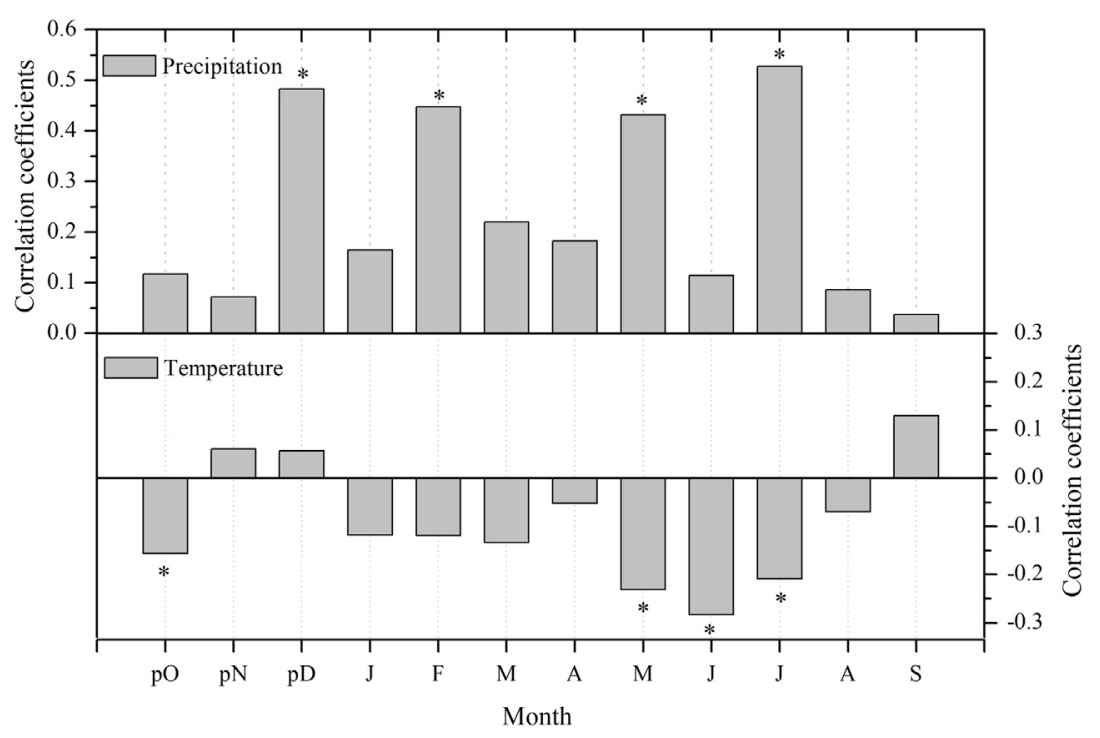

FIGURE 4 |Bootstrap correlation among residual tree-ring chronology and climate variables such as monthly precipitation of Keylong and temperature of Srinagar. The asterisk shows confidence level at 95\%.

annual precipitation during the month of December-July by the WD and ISM does not play any significant role in contributing to its annual budget (Figure 3). Because large scale spatial variability in precipitation exist in the Himalaya due to complex mountain settings and therefore only the station close to the sampling site can explain the tree-growth-climate relationship clearly. Keylong is the only station close to the tree-ring sampling sites but unfortunately, the temperature record is not available from the station. In the absence of temperature data from Keylong, temperature data of Srinagar $\left(34^{\circ} 08^{\prime} \mathrm{N}\right.$ and $74^{\circ} 48^{\prime} \mathrm{E}, 1,587 \mathrm{~m}$ asl; 1900-2008) has been used in the present study which also shows strong consistency in similar climatic zones (Yadav et al., 2004).

\section{Tree-Growth and Climate Relationship}

To understand the climate signal in tree-ring chronology, treegrowth and climate relationship was established using response function analysis (Fritts, 1976). The residual chronology was used for the analysis with climatic variables like temperature and precipitation. Monthly precipitation (1933-1970) and temperature (1900-2008) data were used from previous year's October to the current year's September in correlation analysis using program DENDROCLIM 2002 (Biondi and Waikul, 2004). Bootstrap correlation analysis revealed that tree-growth has direct relationship with precipitation throughout the year (Figure 4). But the previous year's December to current year July (pDcJuly) precipitation plays significant role for tree-growth over the region with significant positive correlation for the previous year December and current year February, May and July months. The eight months (pDcJuly) period contributes $\sim 80 \%$ of annual precipitation and mainly responsible for the tree-growth (Figure 4). Analysis with temperature data revealed an inverse relationship with tree-growth during the whole year except the previous year November, December and the current year September. The previous year October and current year May, June and July months have significantly negative effects on treegrowth (Figure 4), which indicates that increased temperature during these months reduces tree-growth. Overall correlation analysis revealed that cool and wet conditions in the cold-arid Lahaul Himalaya favor and warm and dry conditions hamper tree-growth. The correlation between tree-growth and the previous year's December to the current year's July (pDcJuly) precipitation was used for further analysis and climatic reconstruction.

\section{Calibration, Verification and pDcJuly Precipitation Reconstruction}

The residual chronology of Himalayan blue pine was used in developing the relationship between tree-ring data and climate variables. A strong and significant positive correlation was found with precipitation from the previous year's December to the current year's July. Earlier work by Yadav (2011a) also demonstrated the role of winter precipitation on the radial growth of Cedrus deodara over the cold-arid Lahaul Himalaya. Both studies from the cold-arid Lahaul Himalaya using two different species suggest that the winter precipitation provides vital and favourable conditions for tree-growth advancement. Using this strong relationship as a guide, the previous year's December to current year's July precipitation from AD 1933-1970 was used for the calibration and verification analyses and therefore regression approach has been adopted. Calibration and verification have been done for two different subperiods using 1933-1970 precipitation data. Two sub-periods from 1933 to 1952 and 1953-1970 were successively used once for calibration and then verification. Due to the relatively shorter duration in two different sub-periods, the whole data from 1933 to 1970 was also separately used for calibration. For additional 
TABLE 2 | Calibration and verification statistics of precipitation reconstruction; $\mathrm{ar}^{2}-r^{2}$ adjusted after degrees of freedom, R-Pearson correlation, Sign test, RE (reduction of error), CE (coefficient of efficiency) and L1-Cross-validation using Leave-one-out method (Fritts, 1976; Cook et al., 1999).

\begin{tabular}{|c|c|c|c|c|c|c|c|}
\hline \multicolumn{2}{|l|}{ Calibration } & \multicolumn{6}{|c|}{ Verification } \\
\hline Period & $\operatorname{ar}^{2}(\%)$ & Period & $R$ & Sign test & $t$ value & RE & CE \\
\hline 1933-1952 & 54.4 & 1953-1970 & $0.78[0.0001]$ & $12^{+} / 6^{-}$ & 2.61 & 0.23 & 0.024 \\
\hline 1953-1970 & 59.5 & 1933-1952 & $0.75[0.0001]$ & $13^{+} / 7^{-}$ & 2.13 & 0.38 & 0.251 \\
\hline 1933-1970 & 50.5 & & & & & & \\
\hline $1933-1970 L_{1}$ & 44.8 & 1933-1970 & 0.68 [0.000002] & $26^{+} / 12^{-}$ & 3.08 & 0.46 & \\
\hline
\end{tabular}

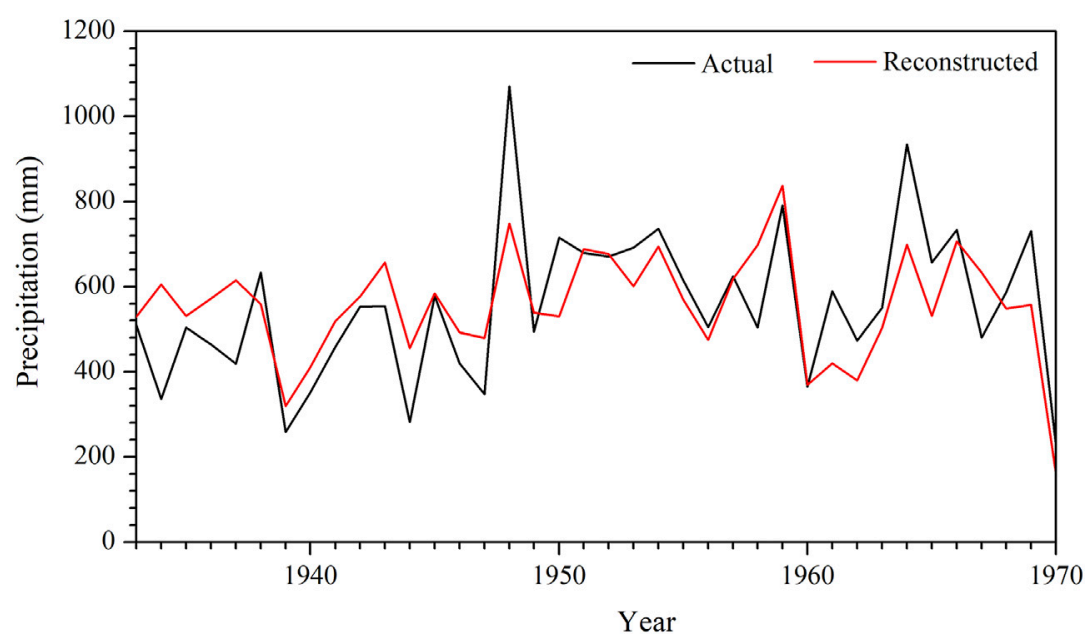

FIGURE 5 | Actual and reconstructed precipitation series plotted together for comparison $(r=0.71,1933-1970, p<0.0001)$.

verification, the leave-one-out cross-validation (Michaelsen, 1987) was also performed. The detailed statistics of calibration and verification of two different sub-periods 1933-1952, 1953-1970 and leave-one-out cross-validation, like Pearson correlation coefficients, Sign test, reduction of error (RE) and coefficient of efficiency (CE) (Fritts, 1976; Cook et al., 1999) were calculated to check reliability and utility of the reconstruction (Table 2). In verification analysis, RE and CE, the most rigorous analysis for validation of the model, values are positive which indicates reconstruction skills. The full period calibration model was used for reconstruction that captured $50 \%$ variance of the instrumental data. The significant correlation and strong year-toyear similarity of the reconstructed series with the monthly precipitation data of pDcJuly was observed $(r=0.71$, 1933-1970, $p<0.0001$ ) (Figure 5).

\section{RESULTS AND DISCUSSION}

\section{Tree-Ring-Width Chronology}

The Himalayan blue pine chronology developed from the coldarid Lahaul Himalaya extends back to AD 1578 (439 years). Twenty-one increment cores from fifteen trees growing over moisture stressed sites at an altitude of $3,076 \mathrm{~m}$ asl, were used for chronology development. The tree-ring width chronology statistics including mean index, mean sensitivity and standard deviation for the chronology span 1730-2016 with EPS level $>0.85$ are shown in Table 1. The strong chronology statistics suggested high consistency among the growth pattern of trees used in the present study. In our field observation, we noted that Himalayan blue pine trees in the forest of Shaligram growing mixed with Himalayan cedar are in the proportion of 1:20. Favourable climatic conditions and ecological requirements of the Himalayan cedar could be the possible reason for such distribution of species. Interestingly, it was also noted that the Himalayan blue pine ring-width chronology also showed similar growth pattern as in Himalayan cedar (unpublished data) growing over the site.

\section{Analyses of pDcJuly Precipitation Reconstruction}

The pDcJuly precipitation reconstruction using the Himalayan blue pine ring-width chronology extends back to AD 1730 (287years), revealed annual to decadal-scale variability (Figure 6). The present reconstruction from the cold-arid Lahaul Himalaya explains $50 \%$ of the variance in the recorded precipitation data of Keylong from the previous year December to the current year July. Such a good relationship among Himalayan blue pine and instrumental records reflected the importance of the species to 


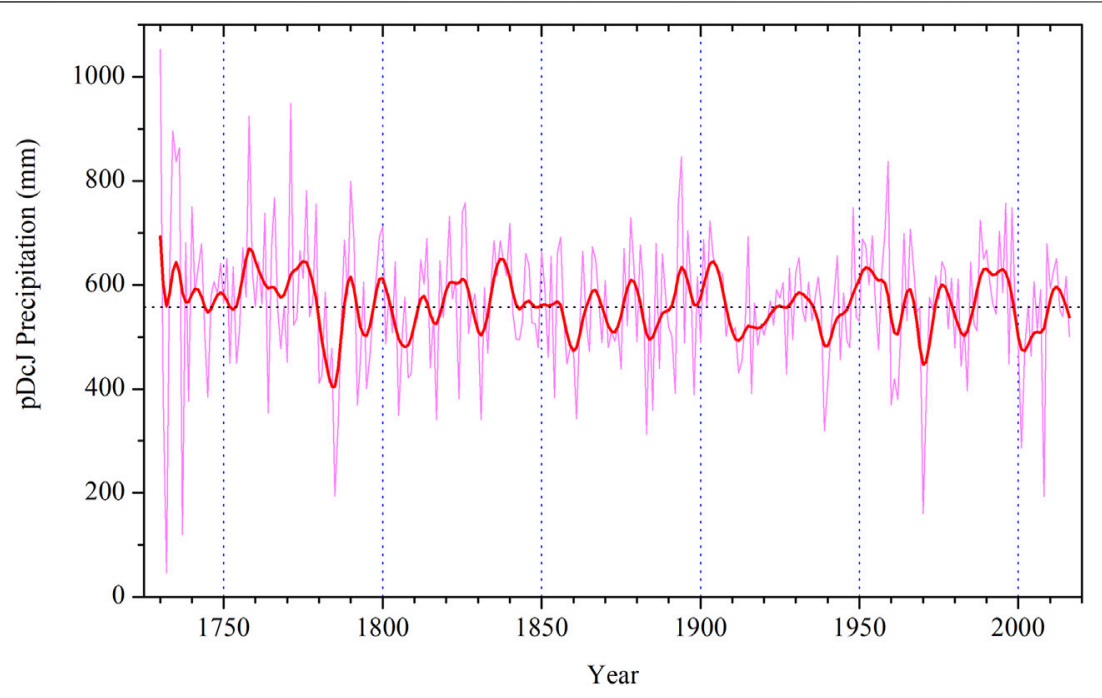

FIGURE 6 | pDcJuly Precipitation reconstruction series (AD 1730-2016) for Shaligram, Lahaul-Spiti, Himachal Pradesh, India. The 10-years low pass filter was applied to the reconstruction (thick superimposed line) to show the precipitation variability in 10 or more year periods. The dotted horizontal line is long term mean of the precipitation reconstruction.

TABLE 3 | The lowest and highest precipitation $(\mathrm{mm})$ year obtained from precipitation reconstruction using the non-over lapping mean of 3-, 5- and 10-years.

3-years mean

Wet

Years

1733-1735

1757-1759

1994-1996

1988-1990

1835-1837

\begin{tabular}{cc}
\multicolumn{2}{c}{ Dry } \\
\hline Years & Prec. \\
\hline $1784-1786$ & 335.7 \\
$1970-1972$ & 369.2 \\
$1833-1835$ & 409.0 \\
$2000-2002$ & 418.9 \\
$1859-1861$ & 430.6
\end{tabular}

$662.8 \quad 1859-1861 \quad 430.6$ 5-years mean

\begin{tabular}{ccccc}
\hline \multicolumn{2}{c}{ Wet } & & & \multicolumn{2}{c}{ Dry } \\
\cline { 1 - 1 } \cline { 5 - 5 } Years & Prec. & Years & Prec. \\
& & & & \\
$1755-1759$ & 662.6 & & $1805-1809$ & 453.6 \\
$1775-1779$ & 651.4 & & $1970-1974$ & 455.7 \\
$1835-1839$ & 650.0 & & $2000-2004$ & 456.0 \\
$1955-1959$ & 639.9 & & $1780-1784$ & 462.8 \\
$1950-1954$ & 637.9 & & $1785-1789$ & 463.7
\end{tabular}

10-years mean

\begin{tabular}{ccccc}
\hline \multicolumn{2}{c}{ Wet } & & \multicolumn{2}{c}{ Dry } \\
\cline { 1 - 1 } \cline { 5 - 5 } Years & Prec. & Years & Prec. \\
& & & & \\
$1950-1959$ & 638.9 & & $1780-1789$ & 463.2 \\
$1770-1779$ & 638.3 & & $2000-2009$ & 486.1 \\
$1990-1999$ & 617.5 & & $1910-1919$ & 509.6 \\
$1750-1759$ & 606.2 & & $1800-1809$ & 520.3 \\
$1900-1909$ & 603.1 & & $1970-1979$ & 525.2
\end{tabular}

reveal the climatic variability over the Lahaul-Spiti region, and our study also suggested that by adding more samples much strong relationship can be found. In the entire reconstructed period, the year 1732 showed the lowest $(45.9 \mathrm{~mm})$ and 1730 highest $(1,053.3 \mathrm{~mm})$ precipitation. Other individual driest and wettest year, those receive the lowest and highest precipitation are also recorded from the past 287-years reconstruction (Table 3). In the entire reconstruction, 1732 is the driest year followed by $1737,1970,2008$, and 1785 , all these years receive precipitation less than $200 \mathrm{~mm}$ in 8 months from the previous year December to the current year July. Similarly, the wettest year 1730 is followed by 1771, 1758, 1734, and 1736, which received precipitation more than $850 \mathrm{~mm}$ in the same period, while the long term mean of pDcJuly precipitation is $562.5 \mathrm{~mm}$. Such high variability in precipitation records from the lowest $45.9 \mathrm{~mm}$ to the highest $1,053.3 \mathrm{~mm}$ in different individual years reveals that the cold desertic Lahaul Himalaya witnessed severe climatic challenges in the past three centuries.
Dry and wet individual years noted in the present reconstruction were matched with other western Himalayan hydrological records. The drought of 1785 and 1970 was also noted in Standardized Precipitation Index (SPI) reconstruction from Kishtwar, Jammu \& Kashmir based on the Himalayan cedar (Singh et al., 2017) and it has been found that in the past 275 years, 1785 is the driest year (SPI -2.3 ) followed by 1971 (SPI -2.2) and 1970 (SPI -2.1). Both studies from two different regions also suggest the intensity of drought which is consistent from Lahaul, Himachal Pradesh to Kishtwar, Jammu \& Kashmir. Low precipitation in 2008 and 1809 in the reconstruction was common with November to april snow water equivalent (SWE) reconstruction from Lahaul-Spiti, Himachal Pradesh (Yadav and Bhutiyani, 2013). Along with very low precipitation in the above mentioned years, some individual high precipitation years such as 1756 and 1730 were also noted in SWE reconstruction, developed from Himalayan cedar tree-ring chronologies, which is similar to the present reconstruction showing high precipitation for the 
Lahaul Himalaya. Continuous low precipitation in two consecutive years revealed that $1731-1732(214 \mathrm{~mm})$ received lowest precipitation and $1734-1735$ (866 $\mathrm{mm})$ highest precipitation. Other biennial low and high precipitation years are 1970-1971, 1732-1733, 1784-1785, and 1758-1759, 1958-1959, 1790-1791, respectively. The drought of 1970-1971 was observed from different parts of western Himalaya such as from cold-arid Lahaul-Spiti, Himachal Pradesh (Yadav and Bhutiyani, 2013), Kumaun Himalaya (Yadav et al., 2015), Kinnaur, Himachal Pradesh (Yadava et al., 2016) and Kishtwar, Jammu \& Kashmir (Singh et al., 2017; Yadav et al., 2017). Spatially such high-intensity drought which has a huge regional impact could be a cause of severe miseries for the socio-economic lives if happens again in the future. 1780-1781 and 2000-2001 drought was also consistent with earlier recorded low precipitation from Lahaul- Spiti, Himachal Pradesh (Yadav and Bhutiyani, 2013). Extreme individual and biennial years correlation with other existing hydrological records from the western Himalaya show utility and reliability of our present precipitation reconstruction. To understand the range of low/high precipitation in the longer timescale we used the non-overlapping mean of reconstructed data. 3-years non-overlapping mean indicated low precipitation in the years 1784-1786, 1970-1972, 1883-1885 and high precipitation in 1733-1735, 1757-1759, 1994-1996. The lowest precipitation of 1784-1786 was consistent with the Kumaun Himalayan drought obtained from 5 years (1782-1786) mean of SPI reconstruction (Yadav et al., 2015) and Kishtwar, Jammu \& Kashmir drought (1784-1788) reconstruction (Singh et al., 2017) which indicate high resemblance in hydrological records from different regions of the western Himalaya.

The low precipitation recorded during the period 1784-1786 also coincided with the Laki volcanic event that occurred in Iceland in 1783. The Laki volcanic eruption in 1783 continued over 8 months and is considered the second largest volcano for producing pyroclastic flow. This eruption supplied a huge amount of aerosols to the atmosphere which created a thick blanket over the northern hemispheric troposphere/stratosphere for more than 5 months and changed the climatic thermal balance for the region (Thordarson and Self, 2003). We believe that the Laki volcanic eruption may be the cause behind such low precipitation between 1783 and 1786 over the western Himalayan region. The western Himalaya receives its largest part of the annual precipitation through westerlies carried moisture from the Atlantic Ocean and Mediterranean Sea. The changes associated with the volcanic events in the northern hemisphere or over Iceland could interrupt the normal atmospheric process/cycle of precipitation by changing the climatic thermal equation. Because of the proximal distance of Iceland to the Atlantic Ocean and Mediterranean Sea, the aerosols and pyroclastic materials produced through volcanoes can strongly disturb the pattern and impact of westerlies and thus precipitation and temperature over Himalaya. Similar to the precipitation, the impression of the Laki volcanic eruption is also marked in the tree-ring-based summer temperature record from Bhutan Himalaya (Krusic et al., 2015). Interestingly, 3-years non-overlapping means indicating low precipitation event from 1815 to 1817 coincided with another volcanic eruption which is Tambora volcano, which erupted in 1815. Tambora volcanic eruption is the largest recorded eruption (Stothers, 1984) which is mainly responsible for the huge destruction and unusual global cooling (Self et al., 2004). Signatures of Tambora volcanic eruption in the form of drought in the year 1816 was also recorded from the Kumaun Himalaya (Yadav et al., 2015) and the semi-arid region of Kinnaur Himalaya (Yadav, 2013). Whereas in Chinese history "Jiaqing famine" is one of the most severe famines that took place in the same period 1815-1817, associated with unusual cooling due to the Tambora volcanic eruption (Gao et al., 2017). Clues about droughts or famines associated with volcanic events offer a fascinating approach toward the understanding of long-term climatic changes and high-resolution tree-ring data from the moisturestressed sites could provide vital tools to understand the nature of such past events. However, robust data would be required to precisely address the past volcanic episodes and their impact on the climate and societies in long-term perspective.

The reconstruction further revealed low and high episodes of precipitation for the Lahaul region with 5 and 10-years nonoverlapping mean of precipitation reconstruction (Table 3). 1780-1789, 2000-2009, 1910-1919 are the driest decades with low precipitation in the reconstruction whereas, 1950-1959, 1770-1779, 1990-1999 are the pluvial decades. These high and low precipitation years were also consistent with exiting hydrological records from western Himalaya, India (Yadav and Bhutyani, 2013; Yadava et al., 2016; Singh et al., 2017). 50-years non-overlapping mean suggest that mid-twentieth (1930-1979) and mid-eighteenth (1730-1779) centuries were associated with pluvial phases with some annual droughts, while droughts due to low precipitation were recorded in the late 18th to early 19th century (1780-1829) and late 19th to early 20th (1880-1929) century with some individual wet years in the reconstruction.

We have also compared the present Himalayan blue pine based precipitation reconstruction ( $\mathrm{pDcJuly}$ ) with previous year August to current year July (pAcJuly) precipitation record of the Lahaul-Spiti region (Yadav, 2011b) to understand the consistency in two distinct precipitation records from the same region with different tree species. The earlier pAcJuly precipitation record was developed using Himalayan cedar samples and in the present study, we have used the Himalayan blue pine to develop the climatic record. The present precipitation record revealed significant correlation $(r=$ 0.49, $p<0.0001, \mathrm{AD} 1730-2008)$ and strong year-to-year consistency with the pAcJuly precipitation record based on the Himalayan cedar (Figure 7). Such a strong resemblance among both the records support the utility and strength of present precipitation reconstruction and advocate the sensitivity of Himalayan blue pine to develop hydroclimatic records from the high-altitudinal semi-arid region of Lahaul-Spiti to understand the long-term regional and global climatic significance.

We have also performed cross-field spatial correlation, using KNMI climate explorer, between reconstructed pDcJuly precipitation and gridded precipitation data CRU TS 4.04 (http://climexp.knmi.nl; Oldenborgh and Burgers, 2005) for the period 1970-2015 and significant positive correlation for the westerly dominated regions was observed for the previous year December to current year July (Figure 8). Negative correlations for the ISM dominated region of eastern Himalaya were also noteworthy in the gridded spatial correlation and indicate the 


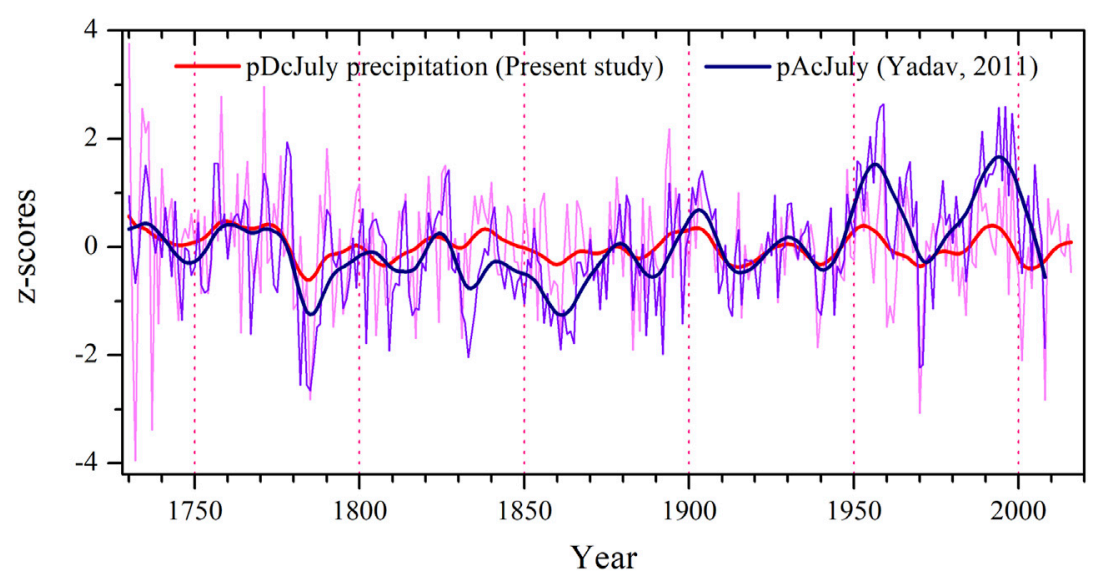

FIGURE 7 | Present pDcJuly precipitation based on Himalayan blue pine and pAcJuly precipitation reconstruction (Yadav, 2011 b) developed using Himalayan cedar plotted together to show the consistency among them. The thick smoothed line over the reconstruction is 20 -years low pass filter.

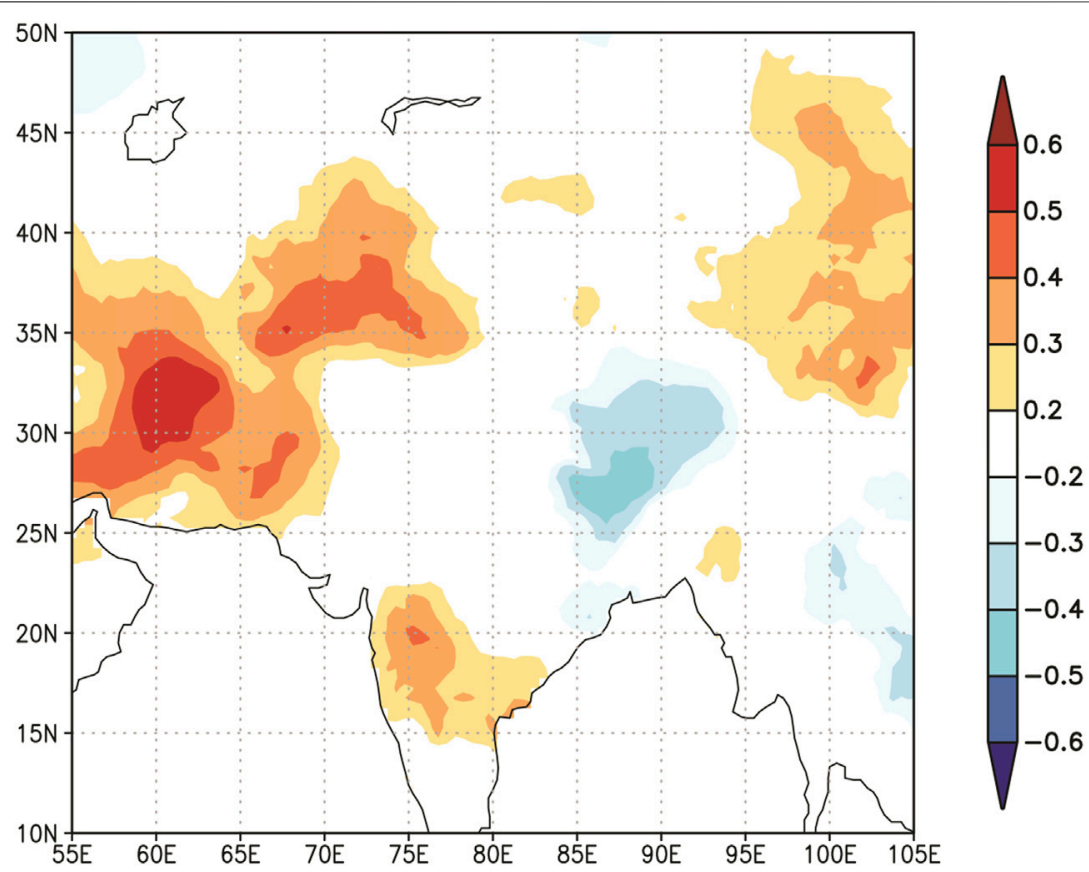

FIGURE 8 | Spatial correlation between gridded data available in http://climexp.knmi.nl (Oldenborgh and Burgers, 2005) and pDcJuly precipitation reconstruction for the period 1970-2015.

opposite relationship for two distinct precipitation regimes. We believe that a network of long and homogenous annually resolved moisture-sensitive Himalayan blue pine tree-ring data from the orography controlled western Himalaya will be very helpful in the future to understand such high variability in the climatic parameters.

\section{Socioeconomic Implication}

In the monsoon shadow zone of western Himalaya variability in winter or westerly influenced precipitation controls the agriculture-based production. In the absence of proper network of canals or other irrigation facilities in terraced farms over the hills of Lahaul Himalaya, winter precipitation becomes the only source to supply necessary moisture to the crops. To explore the socioeconomic implication, agricultural crop production relationship with the reconstructed precipitation data were analyzed. Wheat and barley data available for a limited period from 1987 to 2001 (Department of Agriculture, Himachal Pradesh) was correlated with reconstructed precipitation for the Lahaul-Spiti region 


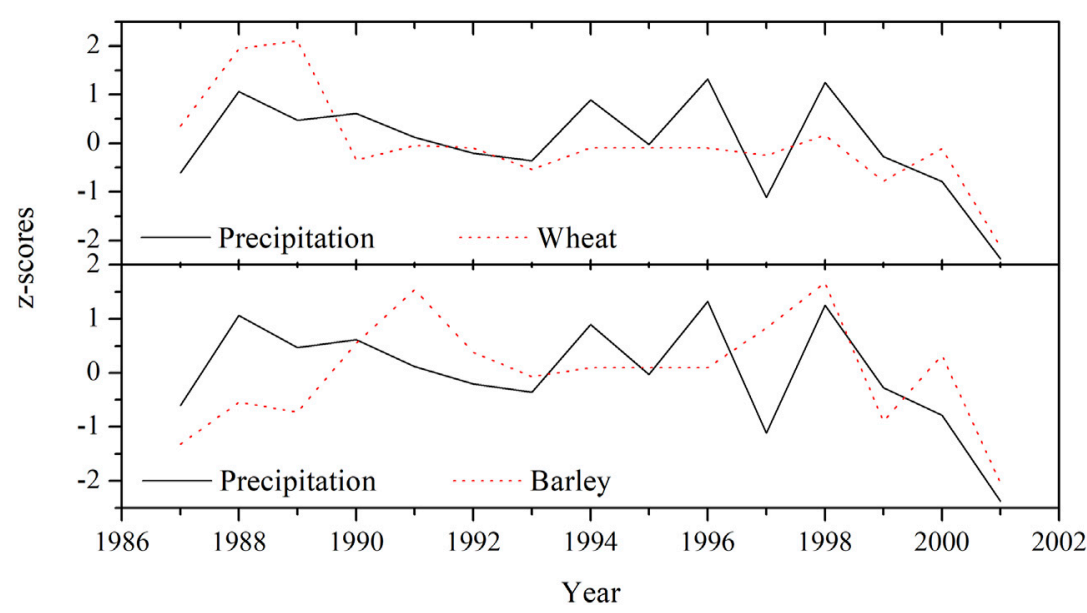

FIGURE 9 | pDcJuly Precipitation reconstruction and wheat-barley productivity from 1987 to 2001 of Lahaul-Spiti plotted together, the data were normalized with respect to mean and standard deviation for the period (1987-2001).

(Figure 1). The agriculture data of wheat and barley showed that in 2001 crop production was very low along with low precipitation in the same year. Due to the widespread drought over southwest central Asia in 1999-2000 decline of agriculture-based production was reported from the Lahaul region (DOA, 2009). 1987, 1993 and 2001 years recorded as dry years in Himachal Pradesh (Ray and Shewale, 2001; Chandel and Brar, 2013) and comparable with the reconstructed data which also showed low precipitation, due to which agricultural production decreased and are consistent with the present reconstruction. Crop production of wheat and barley was comparatively good during the year 1988 which is recorded a drought-free year (Ray and Shewale, 2001). Pearson correlation among reconstructed precipitation and crop production data for the period of 1987-2001 were positive. Wheat and barley data with the reconstruction showed $0.60(p=0.01,1987-2001)$ and 0.47 ( $p=0.07,1987-2001)$ correlations, respectively (Figure 9). Such a good consistency between precipitation and crop productivity shows the strength of tree-ring based precipitation reconstruction to understand the relationship between climate and crop productivity.

\section{CONCLUSIONS}

The present study is the maiden attempt to develop tree-ring based climate reconstruction using tree-ring samples of Himalayan blue pine ( $P$. wallichiana) from Shaligram, cold arid Lahaul, Himachal Pradesh. A 439-years long Himalayan blue pine chronology was developed extending back to AD 1578 and showed strong correlation with monthly climate variables. The ring-width chronology of Himalayan blue pine showed positive correlation with precipitation and negative correlation with temperature. It has been observed that the precipitation from the previous year December to current year July (pDcJuly) is directly associated with tree growth, whereas the temperature of May to July has negative effect on the radial tree-growth.
Based on strong and significant correlation between pDcJuly precipitation and ring-width chronology, precipitation reconstruction was developed back to $\mathrm{AD} 1730$. The reconstruction explains the $50 \%$ variance of the instrumental data over the period from 1933 to 1970. The 287-years precipitation reconstruction indicates year-to-year and decadal-scale variability in the entire reconstruction. The reconstruction revealed low precipitation in the year 1732, $1737,1970,2008,1785$ and high precipitation in 1730, 1771, 1758,1734 and 1736. We also analyzed decades of low and high precipitation with the help of non-overlapping mean of the precipitation series, which showed the period of 1780-1789, 2000-2009 received low and 1950-1959, 1770-1779 high precipitation in the reconstruction. We identified the signature of Tambora and Laki volcanic eruptions induced low precipitation or drought in the reconstructed precipitation during 1815-1817 and 1783-1786, respectively. The spatial correlation between reconstructed precipitation and gridded precipitation data revealed significant correlation for the western Himalayan region. The reconstructed precipitation also showed good correlation with wheat and barley crop production data of Lahaul-Spiti, Himachal Pradesh. Good consistency among Himalayan blue pine induced precipitation reconstruction with earlier hydrological reconstruction from the western Himalaya showed its utility and reliability among other tree species. The large network of high-resolution Himalayan blue pine chronologies with large number of sample replication from the cold-arid Lahaul Himalaya could be very helpful to understand the utility of this species to develop the climatic records as well as its socioeconomic implications over the region in future.

\section{DATA AVAILABILITY STATEMENT}

The data supporting the conclusions of this article will be made available by the authors, without undue reservation. 


\section{AUTHOR CONTRIBUTIONS}

KM and VS drafted the manuscript. KM, VS, and AY collected and cross dated the tee-ring samples. KM, VS, AY, SM, RM and SV evaluated the results. SM arranged the crop productivity data. All authors provided comments to improve the manuscript.

\section{FUNDING}

The research is partially supported by the Science and Engineering Research Board, New Delhi (SB/DGH-76/2013).

\section{REFERENCES}

Bajpai, S. C. (2002). Lahaul-Spiti: A Forbidden Land in the Himalayas. fourth edition. London: Indus Publishing Company.

Biondi, F., and Waikul, K. (2004). DENDROCLIM2002: a C++ Program for Statistical Calibration of Climate Signals in Tree-Ring Chronologies. Comput. Geosci. 30, 303-311. doi:10.1016/j.cageo.2003.11.004

Chandel, V. B. S., and Brar, K. K. (2013). Drought in Himachal Pradesh, India: A Historical-Geographical Perspective, 1901-2009. Trans. Inst. Indian Geogr. 35 (2), 259-273. doi:10.17501/icfow.2018.1102

Cook, E. R. (1985). A Time Series Analysis Approach to Tree-Ring Standardization. Ph.D. thesis. Tucson, Arizona, USA: University of Arizona.

Cook, E. R., Anchukaitis, K. J., Buckley, B. M., D’Arrigo, R. D., Jacoby, G. C., and Wright, W. E. (2010). Asian Monsoon Failure and Megadrought during the Last Millennium. Science 328, 486-489. doi:10.1126/science.1185188

Cook, E. R., Krusic, P. J., and Jones, P. D. (2003). Dendroclimatic Signals in Long Tree-Ring Chronologies from the Himalayas of Nepal. Int. J. Climatol. 23, 707-732. doi:10.1002/joc.911

Cook, E. R., Meko, D. M., Stahle, D. W., and Cleaveland, M. K. (1999). Drought Reconstructions for the Continental United States*. J. Clim. 12, 1145-1162. doi:10.1175/1520-0442

Cook, E. R., and Peters, K. (1997). Calculating Unbiased Tree-Ring Indices for the Study of Climatic and Environmental Change. The Holocene 7, 361-370. doi:10. 1177/095968369700700314

Dahe, Q., Mayewski, P. A., Wake, C. P., Shichang, K., Jiawen, R., Shugui, H., et al. (2000). Evidence for Recent Climate Change from Ice Cores in the central Himalaya. Ann. Glaciol., 31 153-158. doi:10.3189/172756400781819789

DOA (2009). District Agriculture Plan: Lahaul-Spiti, H.P. Department of Agriculture, Himachal Pradesh, 103.

Dubey, B., Yadav, R. R., Singh, J., and Chaturvedi, R. (2003). Upward Shift of Himalayan pine in Western Himalaya, India. Curr. Sci. 85 (8), 25. doi:10.1016/j. quaint.2016.07.032

Fritts, H. C. (1976). Tree-rings and Climate. London: Academic Press.

Gao, C., Gao, Y., Zhang, Q., and Shi, C. (2017). Climatic Aftermath of the 1815 Tambora Eruption in China. J. Meteorol. Res. 31, 28-38. doi:10.1007/s13351017-6091-9

Holmes, R. L. (1983). Computer-assisted Quality Control in Tree-Ring Dating and Measurement. Tree-ring Res. 43, 69-78. doi:10.4324/9781315748689-14

IPCC (2013). Climate Change 2013: The Physical Science Basis. Contribution of Working Group I to the Fifth Assessment Report of the Intergovernmental Panel on Climate Change. Summary for Policymakers. London: Academic Press.

Joshi, L. M., Kotlia, B. S. Ahmad, S. M. Wu, C. C. Sanwal, J. Raja, M., et al. (2017). Reconstruction of Indian Monsoon Precipitation Variability between 4.0 and 1.6 $K a$ BP Using Speleothem $\delta^{18} 0$ Records from the central Lesser Himalaya. India: Saudi Society for Geoscience.

Krusic, P. J., Cook, E. R., Dukpa, D., Putnam, A. E., Rupper, S., and Schaefer, J. (2015). Six Hundred Thirty-Eight Years of Summer Temperature Variability over the Bhutanese Himalaya. Geophys. Res. Lett. 42, 2988-2994. doi:10.1002/ 2015 gl063566

\section{ACKNOWLEDGMENTS}

We sincerely acknowledge Dr. Vandana Prasad, Director, Birbal Sahni Institute of Palaeosciences Lucknow for providing all the necessary facilities, support and permission to publish this work. We also thank the Department of Forest, Government of Himachal Pradesh, India for all necessary help and logistic support during the collection of tree-ring samples and India meteorological department (IMD) for providing climate data. KGM and VS are thankful to the SERB-DST, New Delhi for providing financial assistance (SB/DGH-76/2013). We sincerely thanks to both the reviewers for constructive suggestions which greatly improved the earlier version of the manuscript.

Kumar, P., Dimri, A. P., and Tandon, S. K. (2021). Modeling of Indian Monsoon Extremes during 850-2000AD Using the Proxy-Data from Speleothems. Quat. Int. 12, 33. doi:10.1016/j.quaint.2021.02.009

Michaelsen, J. (1987). Cross-Validation in Statistical Climate Forecast Models. J. Clim. Appl. Meteorol. 26, 1589-1600. doi:10.1175/1520-0450(1987)026<1589: cviscf $>2.0$. co;2

Misra, K. G., Singh, V., Yadava, A. K., Misra, S., and Yadav, R. R. (2020). Treeline Migration and Settlement Recorded by Himalayan Pencil Cedar Tree-Rings in the Highest alpine Zone of Western Himalaya, India. Curr. Sci. 118, 192-195. doi:10.1016/j.quaint.2015.01.015

Oldenborgh, G. J., and Burgers, G. (2005). Searching for Decadal Variations in ENSO Precipitation Teleconnections. Geophys. Res. Lett. 32, L15701. doi:10. 1029/2005GL023110

Osborn, T. J., Biffa, K. R., and Jones, P. D. (1997). Adjusting Variance for SampleSize in Tree-Ring Chronologies and Other Regional-Mean Timeseries. Dendrochronologia 15, 89-99.

Overpeck, J., Liu, K. B., Morrill, C., Cole, J., Shen, C., Anderson, D., et al. (2005). Holocene Environmental Change in the Himalayan-Tibetan Plateau Region: Lake Sediments and the Future. Glob. Chan Mount Reg. 13, 83-92. doi:10.1007/ 1-4020-3508-x_9

Phartiyal, B., Singh, R., Joshi, P., and Nag, D. (2020). Late-Holocene Climatic Record from a Glacial lake in Ladakh Range, Trans-himalaya, India. The Holocene 30, 1029-1042. doi:10.1177/0959683620908660

Ray, K. C. S., and Shewale, M. P. (2001). Probability of Occurrence of Drought in Various Sub-divisions of India. Mausam 52, 541-546. doi:10.31142/ijtsrd19177

Rinn, F. (2003). TSAP-win Time Series Analysis and Presentation for Dendrochronology and Related Applications, Version 0.53 for Microsoft Windows. Heidelberg, Germany: Rinn Tech.

Roxy, M. K., Ritika, K., Terray, P., Murtugudde, R., Ashok, K., and Goswami, B. N. (2015). Drying of Indian Subcontinent by Rapid Indian Ocean Warming and a Weakening Land-Sea thermal Gradient. Nat. Commun. 6, 7423. doi:10.1038/ ncomms 8423

Sahni, K. C. (1990). Gymnosperms of India and Adjacent Countries. India: Shiva offset press Dehradun.

Self, S., Gertisser, R., Thordarson, T., Rampino, M. R., and Wolff, J. A. (2004). Magma Volume, Volatile Emissions, and Stratospheric Aerosols from the 1815 Eruption of Tambora. Geophys. Res. Lett. 31, L20608. doi:10.1029/ 2004gl020925

Shah, S. K., Pandey, U., Mehrotra, N., Wiles, G. C., and Chandra, R. (2019). A winter Temperature Reconstruction for the Lidder Valley, Kashmir, Northwest Himalaya Based on Tree-Rings of Pinus Wallichiana. Clim. Dyn. 53 (7-8), 4059-4075. doi:10.1007/s00382-019-04773-6

Singh, J., Park, W.-K., and Yadav, R. R. (2006). Tree-ring-based Hydrological Records for Western Himalaya, India, since a.D. 1560. Clim. Dyn. 26, 295-303. doi:10.1007/s00382-005-0089-1

Singh, J., and Yadav, R. R. (2005). Spring Precipitation Variations over the Western Himalaya, India, since A.D. 1731 as Deduced from Tree Rings. J. Geophys. Res. 110, D01110. doi:10.1029/2004JD004855

Singh, J., and Yadav, R. R. (2000). Tree-ring Indications of Recent Glacier Fluctuations in Gangotri, Western Himalaya, India. Curr. Sci. 79 (11), 1598-1601. doi:10.1016/j.dendro.2008.09.002 
Singh, J., Yadav, R. R., and Wilmking, M. (2009). A 694-year Tree-Ring Based Rainfall Reconstruction from Himachal Pradesh, India. Clim. Dyn. 33, 1149-1158. doi:10.1007/s00382-009-0528-5

Singh, V., Yadav, R. R., Gupta, A. K., Kotlia, B. S., Singh, J., Yadava, A. K., et al. (2017). Tree Ring Drought Records from Kishtwar, Jammu and Kashmir, Northwest Himalaya, India. Quat. Int. 444, 53-64. doi:10.1016/j.quaint.2016. 09.031

Stokes, M. A., and Smiley, T. L. (1968). An Introduction to Tree-Ring Dating. Chicago: University of Chicago Press.

Stothers, R. B. (1984). The Great Tambora Eruption in 1815 and its Aftermath. Science 224, 4654. doi:10.1126/science.224.4654.1191

Thordarson, T., and Self, S. (2003). Atmospheric and Environmental Effects of the 1783-1784 Laki Eruption: A Review and Reassessment. J. Geophys. Res. 108 (D1), 4011. doi:10.1029/2001JD002042

Treydte, K. S., Schleser, G. H., Helle, G., Frank, D. C., Winiger, M., Haug, G. H., et al. (2006). The Twentieth century Was the Wettest Period in Northern Pakistan over the Past Millennium. Nature 440, 1179-1182. doi:10.1038/ nature 04743

Wigley, T. M. L., Briffa, K. R., and Jones, P. D. (1984). On the Average Value of Correlated Time Series, with Applications in Dendroclimatology and Hydrometeorology. J. Clim. Appl. Meteorol. 23, 201-213. doi:10.1175/15200450(1984)023<0201:otavoc >2.0.co;2

Yadav, R. R. (2012). Over Two Millennia Long Ring-Width Chronology of Himalayan Pencil Cedar from Western Himalaya, India. Curr. Sci. 103, 1279-1280. doi:10.1007/bf02702206

Yadav, R. R. (2011b). Tree Ring Evidence of a 20th-century Precipitation Surge in the Monsoon Shadow Zone of the Western Himalaya, India. J. Geophys. Res. Atmos. 116 (DO2112). doi:10.1029/2010jd014647

Yadav, R. R., and Bhutiyani, M. R. (2013). Tree-ring-based Snowfall Record for Cold Arid Western Himalaya, India since A.D. 1460. J. Geophys. Res. Atmos. 118, 7516-7522. doi:10.1002/jgrd.50583

Yadav, R. R., Gupta, A. K., Kotlia, B. S., Singh, V., Misra, K. G., Yadava, A. K., et al. (2017). Recent Wetting and Glacier Expansion in the Northwest Himalaya and Karakoram. Sci. Rep. 7 (1), 1-8. doi:10.1038/s41598-01706388-5

Yadav, R. R. (2011a). Long-term Hydroclimatic Variability in Monsoon Shadow Zone of Western Himalaya, India. Clim. Dyn. 36, 1453-1462. doi:10.1007/ s00382-010-0800-8

Yadav, R. R., Misra, K. G., Yadava, A. K., Kotlia, B. S., and Misra, S. (2015). Treering Footprints of Drought Variability in Last $\sim 300$ Years over Kumaun
Himalaya, India and its Relationship with Crop Productivity. Quat. Sci. Rev. 117, 113-123. doi:10.1016/j.quascirev.2015.04.003

Yadav, R. R., Park, W-K., Singh, J., and Dubey, B. (2004). Do the Western Himalayas Defy Global Warming? Geophys. Res. Lett. 31, 12-18. doi:10. 1029/2004GL020201

Yadav, R. R., Park, W.-K., and Bhattacharyya, A. (1997). Dendroclimatic Reconstruction of April-May Temperature Fluctuations in the Western Himalaya of India since A.D. 1698. Quat. Res. 48, 187-191. doi:10.1006/ qres.1997.1919

Yadav, R. R., and Park, W.-K. (2000). Precipitation Reconstruction Using RingWidth Chronology of Himalayan Cedar from Western Himalaya: Preliminary Results. J. Earth Syst. Sci. 109 (3), 339-345. doi:10.1007/bf02702206

Yadav, R. R., Singh, J., Dubey, B., and Mishra, K. G. (2006). A 1584-year Ring Width Chronology of Juniper from Lahul, Himachal Pradesh: Prospects of Developing Millennia Long Climate Records. Curr. Sci. 90, 1122-1126. doi:10. 1007/bf02702206

Yadav, R. R. (2013). Tree Ring-Based Seven-century Drought Records for the Western Himalaya, India. J. Geophys. Res. Atmos. 118, 4318-4325. doi:10.1029/ 2012JD01866110.1002/jgrd.50265

Yadava, A. K., Bräuning, A., Singh, J., and Yadav, R. R. (2016). Boreal spring Precipitation Variability in the Cold Arid Western Himalaya during the Last Millennium, Regional Linkages, and Socio-Economic Implications. Quat. Sci. Rev. 144, 28-43. doi:10.1016/j.quascirev.2016.05.008

Yadava, A. K., Sharma, Y. K., Dubey, B., Singh, J., Singh, V., Bhutiyani, M. R., et al. (2017). Altitudinal Treeline Dynamics of Himalayan pine in Western Himalaya, India. Quat. Int. 444, 44-52. doi:10.1016/j.quaint.2016.07.032

Conflict of Interest: The authors declare that the research was conducted in the absence of any commercial or financial relationships that could be construed as a potential conflict of interest.

The handling editor declared a past co-authorship with one of the authors KM.

Copyright (C) 2021 Misra, Singh, Yadava, Misra, Maurya and Vishwakarma. This is an open-access article distributed under the terms of the Creative Commons Attribution License (CC BY). The use, distribution or reproduction in other forums is permitted, provided the original author(s) and the copyright owner(s) are credited and that the original publication in this journal is cited, in accordance with accepted academic practice. No use, distribution or reproduction is permitted which does not comply with these terms. 